\title{
A preliminary check list of the Tabanidae (Diptera) of Costa Rica
}

\author{
By \\ G. B. Fairchild* \\ (Received for publication January 11, 1961)
}

Records of horseflies (Tabanidae) from Costa Rica are not numerous in the literature, and no list of the species reported seems to have been published. At the suggestion of Dr. Rodrigo Zeledón, I have here brought together the available references in the literature together with records of specimens from Costa Rica in my notes and collection, with the hope that it may stimulate others to make collections of these insects and record their observations.

The first notice of Tabanidae from Costa Rica appears to be in the Biologia Centrali Americana in 1886, where Osten SACKen (51) records the presence of two species and describes two others as new, all collected by Rogers. Nearly a generation later, Prof. James S. HiNe of Ohio State University took up the study of Central American Tabanidae, and in a series of papers from 1906 to 1925 , reported the presence of 17 species from Costa Rica, many collected by Pablo Schild at Higuito, San Mateo. Nine of these were described as new species. Following Hine, Herr Otтo KröвER of Hamburg worked extensively on the Neotropical Tabanidae, publishing nearly forty papers on them between 1925 and 1934. Scattered through his publications are references to about 21 species from Costa Rica, of which 12 species were described as new. Much of his material was also collected by Pablo Schild. FaIRCHILD (10-23), though dealing primarily with the Panama fauna, mentions Costa Rican specimens of 15 species, two of which were described as new. Twenty-five species are added to the list in the present publication.

Of the 79 species and varicties here recorded, 13 are doubtful, either probable misidentifications or species whose status is dubious. These have been marked with a query (?). I have seen all of HiNe's types and most of the other material from Costa Rica in his collection. I have also examined the specimens recorded from Costa Rica by Osten SACKEN, including his types, in the British Museum, and have seen Costa Rican specimens of 59 of the species here listed.

* Gorgas Memorial Laboratory, Panama, Republic of Panama 
The arrangement of higher categories follows roughly the scheme proposed by MACKERRAS (50). The assignment of species to genera and subgenera represents my present opinion and is subject to future revision.

\title{
Subfamily PANGONIINAE
}

\author{
Tribe PANGONIINI
}

\section{Genus Esenbeckia Rondani}

Esenbeckia illota osornoi Fairchil 1942, Ann. Ent. Soc. America, 35 (2):196,

Pl. 2, fig. 11(16) 1 q, San Mateo, in Hine coll., Ohio State Univ., recorded by FAIRCHILD (16).

(?) Esenbeckia filipalpis (Williston) 1895, Kansas Univ. Quart., 3: 190.

HINE (30) records the species from Costa Rica, without more definite locality. I suspect this is a misidentification, as filipalpis was described from Paraguay, but as I did not see the specimen in the Hine Collection certainty is not possible.

(?) Esenbeckia fuscipennis var. minor Kröber 1931, Zool. Anz., 94: 248, ơ (39). 1932, Rev. Ent., 2(1) :67-68, q (40), Costa Rica. The brief description of the female suggests $E$. chagresensis Fchld., but since the species was not figured and the type in Budapest now presumably destroyed, it is impossible to recog. nize the species. It is doubtful if it was really a form of fuscipennis Wied.

Esenbeckia prasiniventris (Macquart) 1845, Mem. Soc. Sci. Lille (1844) p. 161, Pl. 3, fig. 9 (47). Recorded by Hine (28) from neat Turrúcares and from Carrillo.

\section{Tribe SCIONINI}

\section{Genus Fidena Walker}

Fidena bicolor Kröber 1931, Zool. Anz., 95 (1-2):36-37, ơ (40), Higuito, San Mateo. Fairchild (20) described the female from a specimen taken in Quepos, Damas, 4 Oct. 1950, by J. R. Kuppers.

Fidena isthmiae Fairchild 1941, Ann. Ent. Soc. America, 34 (3):642-644, fig. 1(11). HINE $(28,30)$ recorded this species as Erephopsis niger Ric. form Peralta Station, Calvert coll. I have seen this specimen. 
Fidena schildi (Hine) 1925, Occ. Pap. Mus. Zool. Univ. Michigan, No. 162, pp. 11-12, \& (30), La Suiza de Turrialba 21, 26 Aug., Pablo Schild coll.

I have seen the types, and other material from Panama.

\section{Genus Scione Walker}

Scione claripennis Ricardo 1900, Ann. Mag. Nat. Hist., (7)VI:292 (56). SzILADY (59) records the species as Sc. costaricana from Turrialba.

FAIRCHILD (16) redescribed and figured the species from Panama material.

Scione maculipennis (Schiner) 1868, Reise Novara, Zool., II, Abt. 1, Vol. B, Dipt. p. 102, Pl. II figs. 7, $7^{\text {a }}$ (57). FaIrChild (16) discussed and figured the species. Several females from Finca Zeledón, Río Coto Brus, 10 Aug. 1958, R. Hartmann coll. The locality is close to the Panama border in Chiriquí Province.

Scione aurea Szilady 1926, Biol. Hungarica, 1 (7):30(59), \&, Suiza de Turrialba, Costa Rica. SzILAdy says this is the same as Sc. incompleta Macq. as determined by Schiner. The description agrees with specimens from Panama determined as maculipennis Schiner by me. KRöBER (44) places aurea as a synonym of Sc. minor Macquart. The identity of incompleta Macq. is uncertain, and Panama specimens were not in agreement with the type of minor Macq. in the British Museum. SzILADY's types were presumably destroyed in Budapest.

\section{Subfamily CHRYSOPINAE}

\section{Tribe CHRYSOPINI}

\section{Genus Chrysops Meigen}

Chrysops melaena Hine 1925, Occ. Pap. Mus. Zool. Univ. Michigan No. 162, pp. 17-19(30). Paratypes from Higuito, San Mateo, Pablo Schild coll. Palmar, Puntarenas, P. and D. Allen colls. KRöBER (44) lists as a synonym of leucospila Wied., but it is distinct. FAIRCHILD (13) figures the wing pattern.

(?) Chrysops. laeta Fabricius 1805, Syst. Antl., p. 112(8). KRöBER (31, 44) reports the species from Costa Rica, without more definite locality.

Chrysops variegata (De Geer), 1776, Mem. Hist. Ins. VI, Pl. 30, fig. 7(5). KRöBER (31) reports specimens of the variety subfascipennis Macq. from San José. The species is common along the coast throughout Central America and the West Indies.

Cbrysops auroguttata Kröber, 1930, Zool. Anz. 90: 71, figs. 6-8 (35). BEQUAERT (2) records the species from Costa Rica, without more definite locality. 1 \&, Wauchope, Limon Prov., 3 June 1954. 
Chrysops calogastra Schiner, 1868, Reise Novara, Dipt., p. 103 (57). 1 , Palmar, Puntarenas, P. and D. Allen colls.

(?) Chrysops latefasciata Bellardi, 1859, Sagg. Ditt. Mess, 1:71, Pl. 2, fig. 15(1). Osten SACKen (51) records from Cachí, Rogers coll., but this is probably melaena Hine.

Chrysops scalarata Bellardi, 1859, Sagg. Ditt. Mess., 1: 72, pl. 2, fig. 19 (1). KRÖBER (31) records the species without specific locality. It occurs commonly on the coast in neighboring Bocas del Toro Province, Panama, and in Honduras and Mexico.

\section{Genus Assipala Philip}

Assipala tanyceras (Osten Sacken), 1886, Biol. Centr. Americana, Dipt., 1: 46(51). Type from Cachí, Rogers coll. Hine (28) records from Peralta Station, March 1910, Calvert coll., and Pechuman (52) adds records of $3 q$ from Navarro Farm., March, W. M. Mann coll.

\section{Subfamily TABANINAE}

\section{Tribe DIACHLORINI}

\section{Genus Diachlorus Osten Sacken}

Diacblorus jobbinsi Fairchild, 1942, Ann. Ent. Soc. America, 35 (3): 296(17); 1946, Ann. Ent. Soc. America, 39 (4):567, Pl. 1, fig. 7(19), Palmar, Puntarenas, P. and D. Allen colls.

\section{Genus Lepiselaga Macquart}

Lepiselaga crassipes (Fabricius) 1805, Syst. Antl., p. 108 (8). Cato, Mar. 1952, Common from Mexico to Paraguay and in the West Indies.

\section{Genus Bolbodimyia Bigot}

Bolbodimyia philipi Stone 1954, Ann. Ent. Soc. America, 47 (2):253254 (58), q. One female paratype in Coll. C. B. Philip is labelled "San José, 1160 M. XI. 1905 P. Biolley". In view of the known distribution of the species, Guatemala to Colombia, this is very probably San José, Costa Rica, as Biolley collected extensively here.

\section{Genus Acanthocera Macquart}

Acanthocera costarricana Fairchild, 1941, Ann. Ent. Soc. America, 34 (3): 647-648, fig. 1 (12). Type from Higuito, San Mateo, Pablo Schild coll. 


\section{Genus Dichelacera Macquart}

\section{Subgenus Dichelacera}

Dichelacera fasciata Walker 1850, Ins. Saund. Dipt., 1: 68 (61) Hine (29) records the species, as analis Hine, from Higuito, San Mateo. KRöBER (37) also records it from San Mateo, as costaricensis Kröb. I have seen specimens also Wauchope, Limon, Aug. 1951, June 1954; San Miguel, June 1954; Palmar, Esquinas, and Golfito, Puntarenas.

Dichelacera regina Fairchild, 1940, Ann. Ent. Soc. America, 33 (4):699700 (9), fig. 3. Hine (28) reported 3 of this species as D. grandis Ricardo from Juan Viñas, Calvert coll. I have seen Hine's specimens labelled Juan Viñas, 30 Aug. 1909, Calvert coll.; Juan Viñas, Schaus coll.; Esparta 22 May, Schaus coll.

Dichelacera melanosoma Hine, 1920, Obio J. Sci., 20 (8):316, fig. 1(29). Type from "Higuito, San Mateo, Pablo Schild coll. A long series of both sexes from Palmar, Puntarenas, P. and D. Allen in M. C. Z.

Dichelacera scapularis Macquart, 1847, Dipt. Exot., Suppl. 2, p. 15(48). 1 , Siquirres, Aug. 1960, Zeledón coll.

Dichelacera submarginata Lutz, 1915, Mem. Inst. Osw. Cruz, 7: 86, Pl. 20, fig. 8(46) 1 q, Orosi, May 1938, H. W. Kumm coll.

Dichelacera princessa Fairchild and Philip, 1960, Stud. Ent., 3 (1-4): 53-55, Pl. 4, fig. 3 (24). Holotype, Allotype and 25 Paratypes from Palmar, Dept. Puntarenas, P. and D. Allen colls. Another specimen from Wauchope, Limon Prov., 9 Aug. 1951.

Dichelacera dorotheae Fairchild and Philip, 1960, Stud. Ent., 3 (1-4): 31-32, Pl. 3, fi. 5; Pl. 7. fig. 5 (24). Holotype and 8 paratypes from Esquina, near Golfito, Dept. Puntarenas, P. and D. Allen colls.

\section{Subgenus Psalidia Enderlein}

Dichelacera fulminea Hine form ocellata Enderlein 1925, Mitt. Mus. Berlin, 11: 393(6). Hine (29) records a specimen as Tabanus festivus Hine, not Wied. from Costa Rica. In the Hine collection there are two females, one labelled Costa Rica, the other La Suiza de Turrialba. I have a specimen from Wauchope, Limon, 9 Aug. 1951.

\section{Subgenus Catachlorops Lutz}

Dicbelacera umbratus (Hine) 1920, Obio J. Sci., 20 (6): 187-188(29). Type female from Higuito, San Mateo, Pablo Schild coll, in U. S. N. M. 


\section{Genus Stypochela Enderlein}

Stypocbela badia (Kröber) 1931, Rev. Ent., 1: 402, fig. 3 (37). The specimen recorded by HINE (28) as Tabanus venenatus O.S. from Peralta Station, 10 Mar. 1910 proves on examination to be the present species, although HIN E subsequently decided it was the same as St. peruviana (Bigot), a closely related form.

\section{Genus Stibasoma Schiner}

\section{Subgenus Stibasoma}

Stibasoma chionostigma (Osten Sacken) 1886, Biol. Centr. Americana, Dipt., 1: 54, Pl. 1, fig. 11 (51). Recorded by HiNe (1917) from Guácimo, June 6, 1909. Calvert coll., as St. flavistigma Hine. I have seen this specimen, now in the Academy of Natural Sciences, Philadelphia.

Stibasoma fulvobirtum (Wiedemann) 1828, Auss, zweifl. Ins., 1: 155(62). 1 \%, Wauchope, Limon Prov., 9 Aug. 1951.

Stibasoma panamensis Curran 1934, Fam. Gen. N. A. Dipt., p. 153, fig. 23(4). Recorded by Fairchild (21) from 'Wauchope, Limon, 9 Aug. 1951.

\section{Subgenus Rhabdotylus Lutz}

Stibasoma venenata (Osten Sacken) 1886, Biol. Centr. Americana Dipt. 1: 54 (51). 1 o, Carrillo, May 1903, C. F. Underwood coll. agreed ith the types in the British Museum.

\section{Genus Chlorotabanus Lutz}

Cblorotabanus mexicanus (Linnaeus) 1767, Syst. Nat., 12th ed., 1, pt. 2, p. 1000(45). Philip and Fairchild (55) report a specimen from Finca Suerre.

Cblorotabanus inanis (Fabricius), 1794, Ent. Syst., IV, p. 368(7), PHILIP and Fairchild (55) mention from Costa Rica, without definite locality, but I cannot now trace the authority for this, though it undoubtedly occurs.

\section{Genus Phaeotabanus Lutz}

Phaeotabanus longiappendiculatus (Macquart) 1855, Dipt. Exot., Suppl. 5: 32(49) 1 \%, Palmar, Puntarenas, 28 Nov. 1949, Trapido and Allen coll.

Pbaeotabanus atopus (Fairchild) 1953 Ann, Ent. Soc. America, 46 (2): 271.272, Pl. 1, fig. 3(21). 1 o, Palmar, Puntarenas, P. and D. Allen colls. 


\section{Genus Stenotabanus Lutz}

\section{Subgenus Stenotabanus}

Stenotabanus fulvistriatus (Hine) 1912, Obio Nat., 12 (7): 515(27). A specimen in the Hine Collection is labelled Higuito, San Mateo, Pablo Schild coll. I have also seen material from Palmar, Puntarenas, P. and D. Allen Colls.

Stenotabanus plenus (Hine) 1907, Obio Nat., 8 (2): 225(26). Fairchild (17) records $5 \%$ from Higuito, San Mateo in the Hine Collection.

Stenotabanus maculifrons (Hine) 1907, Obio Nat. 8 (2): 222-223(26). Palmar and Golfito, Puntarenas, P. and D. Allen.

Stenotabanus pequeniensis Fairchild 1942, Ann. Ent. Soc. America, 35 (3): 308-309, fig. 13(17). Palmar, Puntarenas, P. and D. Allen.

Stenotabanus xenium Fairchild 1946, Ann. Ent. Soc. America, 39 (4): 568.569 (19), fig. 5. 1 F Finca Margarita, May 1938, Kumm coll.

Stenotabanus lerida Fairchild 1942, Ann. Ent. Soc. America, 35 (3): 307-308(-17) fig. 14. 1 q, Carillo, C. F. Underwood coll.; San Carlos, Zeledón coll.

(?) Stenotabanus sp. $1 \delta^{*}$, Palmar, Puntarenas, P. and D. Allen colls. This may be the undescribed male of St. (Brachytabanus) longipennis Kröb.

\section{Tribe TABANINI}

\section{Genus Hemichrysops Kroeber}

The use of this name rather than Pbilipotabanus is necessitated by considerations of priority, as noted earlier (FAIRCHILD, 22). Philipotabanus is retained in a subgeneric sense for the species with an irregular fenestrate wing pattern. Whether the group belongs in Diacblorini or Tabanini is still undecided, as the two groups are not well defined in the Neotropics.

\section{Subgenus Hemichrysops}

Hemichrysops vecordis Fairchild 1956, Smithsonian Miscell. Coll., 131 (3): 16 (22). New name for $H$. fascipennis Kröber 1930, not Macquart. 1 , Carillo, C. F. Underwood in the British Museum. 
1: 49(51). Type from Irazú, Rogers coll. Several females from Finca Zeledón, Río Coto Brus, 20 Aug. 1958, R. Hartmann coll.

Hemicbrysops magnificus (Kröber) 1934, Rev. Ent., 4. (3): 305 (44). Recorded by KRöBER (44) as Tabanus (Phaeotabanus) and by FAIRCHILD (18, 21) as Tabanus (Pbilipotabanus) from Higuito, San Mateo; Suretka, May 1924, J. C. Bradley coll.; Esquinas, Puntarenas, P. and D. Allen. Later material has been seen from San Miguel, San Ramón Esparta; Golfito; Dominical, T. H. G. Aitken coll.; San Carlos, Zeledón coll. Specimens in the Hine coll. from Juan Viñas and Higuito are labelled alteripennis.

Hemichrysops medius (Kröber) 1934 (44), nom. nov. pro Tabanus intermedius Kröber 1930, Zool. Anz. 90: 81(35), not Walker 1848, Suiza de Turrialba (type). Another specimen, Tapantí, Cartago 9 May 1960, was sent for identification by Dr. Zeledón. This is not Pbilipotabanus medius Fairchild (18) which equals pallidetinctus Kröber.

Hemichrysops pallidetinctus (Kröber) 1930, Zool. Anz., 86 (11-12): 297 298, fig. 19(34). This is the species erroneously treated as medius Kröber by me in 1942 (18) and in 1953 (21) as caliginosus Bell. Type comparisons by Dr. C. B. Philip and myself and more careful study of descriptions, now show that caliginosus with its synonym alteripennis Walk. is a Mexican species, while medius Kröb. and pallidetinctus are apparently distinct. Hine lumped all his material from Central America under caliginosus or alteripennis, but examination of these shows that his Costa Rican specimens belong to two species, magnificus Kröb., already discussed, and the present species. $10^{\top}$, Higuito, and $2 q$, La Suiza, Turrialba in the Hine coll.

\section{Genus Leucotabanus Lutz}

Leucotabanus exaestuans (Linnaeus) 1767, Syst. Nat. ed. 12, 2: 1000. $=$ L. leucaspis Wied. 1828. Wauchope, Limon Prov., 3 June 1954(45).

Leucotabanus flavinotum (Kröber) 1934 (44), nov. nom. pro T. nigriflavus Kröb., 1931, Konowia 10: 292(41). FaIRCHILD (10) records from Costa Rica, without more definite locality.

\section{Genus Tabanus Linnaeus}

Tabanus lineola var. carneus Bellardi 1859. FaIRCHILD (15) has disçussed this species and its various forms, which are widespread throughout tropical America. Punta Rieles, Golfito, 14 May 1943, T. Aitken coll.; Damas., Quepos, 5 July 51, Kuppers coll.; Turrialba, 30 Mar. 13 April, 1949, Neel coll.; Palmar, Puntarenas, P. and D. Allen; San Carlos, Zeledón coll. Specimens in the Hine coll. are from San Mateo. 
Tabanus lineola var. plangens Walker 1854. San Miguel, 5 June 1954. Hine (25) reported specimens from Carrillo as T. modestus Wied.

Tabanus lineola var. stenocephalus. Hine 1906(25). Cato, March 1952; Dominical, T. Aitken coll.

Tabanus trivittatus Fabricius 1805, Syst. Antl., p. 104(8). T. fumatipennis Kröber 1933 and Fairchild 1942 (15) is a synonym according to PHILIP (53). 3 \& Higuito San Mateo, Schild coll, and 1 \&, San Carlos, Schild and Burgdorf, all in U.S.N.M. Palmar, Puntarenas, P. and D. Allen colls. HiNe (25) reported specimens from San Carlos under this name.

Tabanus unistriatus Hine 1906., Obio Nat., 7 (2): 28(25). San Carlos, types in U.S.N.M. Wauchope, Limon, 9 Aug. 1951; Siquirres, Aug. 1960. Dogles coll. There are also specimens in the Hine collection from Piedras Negras and Carrillo, as reported by FaIRCHILD (15).

(?) Tabanus costaricensis Kröber, 1931, Konowia, 10 (4): 294-295(41), q, Costa Rica. This species has not been identified since its descriptions. The type is in Vienna where it has been studied by Dr. C. B. Philip, who writes that he does not recognize it and suspects it may not be Neotropical.

(?) Tabanus griseopleuris Kröber, 1931, Konowia, 10 (4): 295-296(41), $\uparrow$, Costa Rica. From the description, I believe this species is probably a synonym of T. quinquepunctatus Hine 1925, a species overlooked by KRöBER in his catalo. gue (44). I have seen Hine's species, described from Guatemala, also from British Honduras and Panama. Kröber's type was in Hamburg and presumably destroyed during the war.

(?) Tabanus lacajaensis Kröber 1931, Stell. Ent. Zeit., 92 (1-2: 303 (36), q, La Caja, $8 \mathrm{Km}$. West of San José, C.R. Type in Hamburg, presumably destroyed. From the description, this species would appear similar to $T$. haemagogus Will, and T. umbraticolus Fchld., but its identity is uncertain.

Tabanus ratus Kröber, 1934, Rev. Ent., 4 (3): 313(44), new name for T. validus Hine 1920, nec Wiedemann 1828. I have a specimen from Palmar, Feb. 1951, D.O. Allen coll, which agreed with the type of validus in U.S.N.M.

(?) Tabanus fenestra Williston 1887 from the West Indies was listed by KRÖBER (44) from Costa Rica, probably in error. Kröber's Costa Rican material may have been Stenotabanus pequeniensis Fchld. or St. xenium Fchld., similar appearing species. There are $2 \%$, labelled Costa Rica under this in the Hine collection, but their true status remains to be determined. 
name for $T$. apicalis Macq. 1841, not Wiedemann 1828. Bellardi (1), however, had already renamed Macquart's species, whose type is headless, as bigoti Bell. The identity of Kröber's specimens from Costa Rica is thus uncertain.

Tabanus erebus Osten Sacken 1886, Biol. Centr. Americana, Dipt. 1: 50(51). KRöBER (37) recorded the species as Astigmatophthalmus satanas Kröb. from Turrialba, and I have seen $6 q$ from various localities in Costa Rica in the Hine collection.

Tabanus nebulosus De Geer 1776, Mem. serv. bist. Ins., 6: 227, Pl. 30, fig. 2(5). 1 \%, Palmar, Feb. 1951, T.H.G. Aitken coll.

Tabanus pungens Wiedemann, 1828, Auss. Zweifl. Ins. 1: 175(62). A widespread species with numerous synonyms, among which are desertus Walker and angustivittata Kröb. 1 \%, Turrialba, 7 Apr. 1949, W. W. Neel Coll.

Tabanus xenorbynchus Fairchild 1946, Ann. Ent. Soc. America, 39 (4): 572-573, Pl. 1, fig. 1(19). 1 \%, Punta Rieles, Golfito, 14 May 1943, T. Aitken coll. (paratype).

Tabanus punctipleura Hine 1920. Obio 1. Sci., 20:314 (29). San Carlos; Carrillo; (types).

Also fairly common in neighboring Bocas del Toro Prov., Panama.

Tabanus pruinosus Bigot, 1892, Mem. Soc. Zool. France, 5: 683(3). KRöBER (41) redescribes as T. schmidti from La Caja, near San José. I have it also from Chiriqui, Panama.

Tabanus albocirculus Hine 1907, Obio Nat., 8: 227(26). Tucurrique, Schild. and Bergdorf colls. (type). Wauchope, Limon, 9 Aug. 1951, Trapido and Galindo colls. Another specimen from Arenas, 20 Sept. 1950, is the smaller reddish form.

Tabanus oculus Walker, 1848, List Dipt. Brit. Mus., 1: 157 (60). 1 , Palmar, Puntarenas, P. and D. Allen colls.

Tabanus defilippii Bellardi, 1859, Sagg. Ditt. Mess., 1: 57(1). KRÖBER (32) records this species from Carrillo, but later (33) realized that he was really dealing with punctipleura Hine. It is however, very likely that defilippi does occur in Costa Rica, as it is common in nearby Bocas del Toro Prov., Panama, though it is primarily a tree-top species.

(?) Tabanus fumomarginatus Hine, 1929(29), was reported by Kröber from Carrillo, probably in error. His specimens may have been the closely similar 
T. polyphemus Fairchild, known from Mexico to Panama.

Tabanus bigoti Bellardi, 1859, Sagg. Ditt. Mess., 1:58(1). 1 , Wauchope, Limon 3 June 1954, Trapido and Galindo colls. This is the species treated by FAIRCHILD as bigoti var. B. (18).

(?) Hybostraba albovillosa Kröber, 1931, Stett. Ent. Zeit., 92: 92(36), $\mathrm{O}^{\lambda}$, Costa Rica. The genus was proposed for male Tabanidae with the eyes pilose and an area of much enlarged facets. It is probably a synonym of Tabanus. The present species has not been recognized nor have females been associated. The most similar regional species seems to be $T$. pruinosus Bigot. Dr. C. B. Philip (in litt.) writes that males of pruinosus agree quite well with Kröber's description.

Poeciloderas platyventris Kröber, 1931, Zool. Anz., 94 (3-4): 88-89(38), fig. 29, $\&$, Costa Rica. I believe this to be no more than a poorly preserved specimen of P. quadripunctatus. Dr. Philip has examined the type in Vienna and agrees.

Poeciloderas quadripunctatus (Fabricius), 1805, Syst. Antl., p. 99(8). Osten SACKen (5) reported a specimen from Rio Sucio, Rogers coll., while HINE (28) reported specimens from Juan Viñas and Cerro Jocosal and (30) from Higuito as $T$. punctipennis Macq., a synonym. Kröber's (38) material was from La Caja, near San Jose. I have seen the following material: San Jose, 16 Aug. 1944, Fairchild coll. Mercedes Sur, Puriscal, San José, 10 Apr. 1960, Wille coll.; Sabana, 1960, Zeledon coll.

\section{SUMMARY}

A list, with localities, of the 66 species and varieties of Tabanidae known from Costa Rica is given. An additional 13 species of uncertain status, either probable misdeterminations or unrecognized species, have been reported in the literature and are included here with a query. The references include publications containing aids to the identification of species as well as those containing records of Costa Rica species.

\section{RESUMEN}

Se presenta un catálogo, con localidades, de las 66 especies y variedades de Tabanidae conocidas de Costa Rica. Se incluyen, marcadas con signo de interrogación, otras 13 species de estado incierto, o especies no reconocidas o bien identificaciones erróneas, que se han mencionado en la literatura. En la bibliografía se incluyen trabajos útiles en la identificación de especies así como los que contienen mención de ejemplares costarticenses. 


\section{REFERENCES*}

1. Bellardi, L.

1859-1862. Saggio di Ditterologia Messicana, Pt. 1, pp. 1-80, 2 plates (1859); Pt.

2, pp. 1-99, 2 plates (1862); Appendice, pp. 1-28, 1 plate (1862).

2. Bequaert, J.

1940. Tabanidae of the Island of Trinidad, B.W.I. Bull. Ent. Res., 30(4): 447-453.

3. Bigot, J.M.F.

1892. Descriptions de dipteres nouveaux. Mem. Soc. Zool. France, 5: 602-691.

4. Curran, C.H.

1934. The families and genera of North American Diptsia, pp 1.512, illust.

5. DeGeer, C.

1776. Mémoirs pour servir a l'Histoire des Insertes, Vol. 6

6. ENDERLEIN, G.

1925. Grundlagen eines neuen Systems der Tabaniden. Mitt. Zool. Mus. Berlin, 11: $255-409$, 1 fig.

7. Fabricius, „J. C.

1794. Entomologia Systematica, Vol. 4.

8. Fabricius, J. C.

1805. Systema Antliatorum. Brunsvegiae.

9. FAIRCHILD, G. B.,

1940. Notes on Tabanidae from Panama II. The Genus Dichelacera and related genera. Ann. Ent. Soc. America, 33(4): 683-700, 2 plates.

10. FAIRChILD, G. B.

1941. Notes on Tabanidae form Panama VI. The genus Fidena. Ann. Ent. Soc. America, 34(3): 629-638, 8 figs.

11. FaIRChILD, G. B.

1941. Notes on Tabanidae form Panama VI. The genus Fidena. Ann. Ent. Soc. America, 34(3): 639-646, 6 figs.

12. FAIRCHILD, G. B.

1941. A new Acanthocera from Central America. Ann. Ent. Soc. Anerica, 34(3): 647-648, 1 fig.

13. FAIRCHILD, G. B.

1942. Notes on Tabanidae from Panama III. The genus Chrysops. Proc. Ent. Soc. $W$ asbington, 44(1): 1-8, 1 plate.

14. FaIRChILD, G. B.

1942. Notes on Tabanidae from Panama. V. The genus Tabanus, subgenus Bellardia. Psyche, 49(1-2): 8-17, 1 plate.

15. FAIRCHILD, G. B.

1942. Notes on Tabanidae from Panama. VII. The subgenus Neotabanus: Ann. Ent. Soc. America, 35(2): 153-182, 2 plates.

* In addition to references cited in the text, a few publications which may be useful in the identification of Costa Rican specimens have been added. 
16. FAIRCHILD, G. B.

1942. Notes on Tabanidae from Panama VIII. The genera Pityocera, Scione and Esenbeckia. Ann. Ent. Soc. America. 35(2): 183-199, 2 plates.

17. Fairchild, G. B.

1942. Notes on Tabanidae from Panama IX. The genera Stenotabanus, Lepiselaga and related genera. Ann. Ent. Soc. America, 35(3): 289-309, 1 plate.

18. FAIRCHILD, G. B.

1942. Notes on Tabanidae from Panama X. The genus Tabanus and resume of the Tabanidae of Panama. Ann. Ent. Soc. America. 35(4): 441-474, 2 plates.

19. FAIRCHILD, G. B.

1946. Additional notes on the Tabanidae of Panama. Ann. Ent. Soc. America, 39(4): 564-575, 1 plate.

20. FAIRCHILD, G. B.

1951. Descriptions and Notes on Neotropical Tabanidae, Ann. Ent. Soc. America, $44(3)$ : 441-462, 11 figs.

21. FAIRCHILD, G. B.

1953. Notes on Neotropical Tabanidae with descriptions of new species. Ann. Ent. Soc. America, 46(2): 259-280, 2 plates.

22. FAIRCHILD, G. B.

1956. Synonymical notes on Neotropical flies of the family Tabanidae. Smithsonian Miscell. Coll., 131(3): 1-38.

23. FAIRChILD, G. B.

1958. Notes on Neotropical Tabanidae II. Descriptions of New Species and New Records for Panama. Ann. Ent. Soc. America, 51(6): 517-530, 2 plates.

24. FairChild, G. B. \& C. B Philip.

1960. A revision of the Neotropical genus Dichelacera, subgenus Dichelacera Macquart. Studia Entomologica 3(1-4): 1-86, 9 plates.

25. HINE, J. S.

1906. The North American species of Tabanus with a uniform middorsal stripe. Ohio Nat., 7: 19-28.

26. HiNe, J. S.

1907. Descriptions' of new North American Tabanidae. Obio Nat., 8: 221-230.

27. HiNe, J. S.

1912. Five new species of North American Tabanidae, Obio Nat., 12(7): 513-516, Plate 25.

28. HINE, J. S.

1917. Costa Rican Diptera collected by P. P. Calvert. Trans. American Acad. Sci., 43: 291-229.

29. HINE, J. S.

1920. Descriptions of horseflies from Middle America. Obio Jr. Sci., 20(6): 185192; (8): 311-319. 
30. HiNe, J. S.

1925. Tabanidae of Mexico, Central America and the West Indies.Occ. Papers Mus. Zool. Univ. Michigan, $\mathrm{N}^{\circ} 162$, pp. 1-35.

31. KRÖBER, O.

1925. Die Chrysops-arten Sud- und Mittelamerikas, nebst den arten der Inselwelt und Mexikos. Konowia, 4(3-4): 210-256, 319-375, 5 plates

32. KRÖBER, O.

1929. Uber einige kleinere Gattungen der sudamerikanischen Tabaniden. Zool. Anz., 83(1-4): 47-63; (5-8): 115-137.

33. KRÖBER, O.

1930. Nachtrage zu den kleinen Gattungen der sudamerikanischen Tabanini, Zool. Anz., 86(9-10): 248-265, 8 figs.

34. KRÖBER, O.

1930. Die Tabaniden Untergattung Phaeotabanus. Zool, Ans., 86(11-12): 273-300, 21 figs.

35. KRÖBER, O.

1930. Neue Tabaniden und Zusatz zu bereits beschriebenen. Zool. Anz. 90: 69-86, 21 figs.

36. KRÖBER, O.

1931. Neue sud- und mittelamerikanische Arten der Dipterengattung Tabanus. Stett. Ent. Zeit., 92(2): 275-305.

37. KRÖBER, O.

1931. Neue neotropische Tabaniden aus den Unterfamilien Bellardiinae und Tabaninae. Rev. Ent., 1(4): 400-417, 18 figs.

38. KRÖBER, O.

1931. Die Tabanus-Gruppen Straba und Poecilosoma (Hybostraba und Hybopelma) der neotropischen Region. Zool. Anz., 94(3-4): 67-89, 20 figs.

39. KRÖBER, O.

1931. Neue Arten aus dem Genus Esenbeckia Rond. Zool. Anz. 94: 245-257, 7 figs.

40. KRÖBER, O.

1931. Neue Arten der Gattung Fidena. Zool. Anz. 95: 17-37,19 figs.

41. KRÖBER, O.

1931. Dreizchn neue neotropische Tabanusarten. Konowia, 10(4): 291-300.

42. KRÖBER, O.

1932. Das Genus Esenbeckia Rondani und die Gymnocbela-Untergattung Amphichlorops Lutz. Rev. Ent., Rio de Janeiro, 2(1): 52-93, 32 figs.

43. KRÖBER, O.

1932. Bemerkung über die Systematik der neotropisches Tabaniden, nebst Bestimmungs-tabelle der Subfamilien und Gattungen. Rev. Ent., 2(2): 185-202, 2 figs. 
44. KRÖBER, O.

1934. Catalogo dos Tabanidae da America do Sul e Central, incluindo o Mexico e as Antilhas. Rev. Ent. 4(2-3): 222-276, 291-333.

45. IINNAEUS, C.

1767. Systema Naturas, 12th Ed.

46. LuTz, A.

1915. Tabanidas do Brasil e de alguns Estados vizinhos. Segunda Memoria. Mem. Inst. Osw. Cruz, 7: 51-119, P1. 19-21.

47. MACQUART, J.

1845. Diptères exotiques nouveaux ou peu connus, Mem. Soc. Roy. Sci. Agric. Arts. Lilie, 1844: 133-364, Pl. 1-20. (Reprinted as Diptères. Exotiques, Supplement 1, pp. 1-238, Pl. 1-20, 1846, Librairie Encyclopedique de Roret, París).

48. Macquart, J.

1847. Diptères Exotiques, etc., 1846, pp. 21-120, Plates 1-6 (Reprint, Suplement 2, ${ }^{\circ}$ pp. 1-104, Pl. 1-6).

49. MACQUART, J.

1855. Diptères Exotiques, etc. 1854, pp. 25-156, Plates 1-7 (reprint, supplement 5, pp 1-136, Plates 1-7).

50. MACKERRAS, I. M.

1955. The Clasification and Distribution of Tabanidae II. History: Morphology: Classification: Subfamily Pangoniinae. Aust. J. Zool. 3(3): 439-511, 39 figs.

51. Osten SaCken, C. R.

1886. Biologia Centrali Americana, Insecta, Diptera 1: 43-60.

52. Pechuman, L. L.

1937. Notes on some Neotropical species of the genus Chrysops. Rev. Ent., 7(2-3): 134-141.

53. Philip, C. B.

1954. New North American Tabanidae, VIII. Notes on and keys to the genera and species of Pangoniinae exclusive of Chrysops. Rev. Brasil. Ent., 2: 13-60. 10 figs.

54. Philip, C. B.

1955. New North American Tabanidae IX. Notes on and keys to the genus Chrysops. Rev. Brasil. Ent., 3: 47-128.

55. Philip, C. B. ANd G. B. Fairchild.

1956. American biting flies of the genera Chlorotabanus and Cryptotylus. Ann. Ent. Soc. America, 49(4): 313-324, 1 fig., 1 plate.

56. RICARDO, G.

1900. Descriptions of five new species of Pangonia from South America. Ann. Mag. Nat. Hist., Ser 7, 6: 291-294. 
57. SCHINER, J. R.

1868. Reise der Oesterreichischen Fregatte Novara. Zoologische Theil. Diptera, VI, + 388 pp., Plates 1-4.

58. StONe, A.

1954. The genus Bolbodimyia Bigot. Ann. Ent. Soc. America, 47(2): 248-254.

59. SZILADY, Z.

1926. New and Old World Horseflies. Biol. Hungarica, 1(7): 1-30, pl. 4.

60. WALKeR, F.

1848, List of the specimens of dipterous insects in the collection of the British Museum, Part 1, pp. 1-299.

61. WALKER, F.

1850. Insecta Saundersiana: or character's of undescribed insects in the Collection of W. W. Saunders, I. Diptera, pt. 1. pp. 1-75, 2 plates.

62. WIedemanN, C. R. W.

1828. Aussereuropäiscbe zweiflugliche Insekten, 1: I-XXXXII, 1-608, 5 plates. 